\title{
Intraoperative Tachycardia- Reset by Single Shot Short Acting Beta Blocker
}

\section{Opinion}

Beta-adrenergic receptor blockers ( $\beta$ blockers) have been used for preventing or treating tachycardia, hypertensive crisis, ischemic cardiomyopathy and arrhythmias (perioperatively). Myocardial depression and bradycardia associated with $\beta$ blockers is attributed to sympathetic nervous system blockade rather to membrane stabilization [1]. Surgical procedures are associated with perioperative tachycardia and increased myocardial contractility leading to an increased oxygen demand [2]. 2009 AHA update on $\beta$ blockers states that "The usefulness of beta blockers is uncertain for patients who are undergoing either intermediate risk procedures or vascular surgery in whom preoperative assessment identifies a single clinical risk factor in the absence of coronary artery disease" [3].

Hypovolemia, light plane of anesthesia, hypercarbia, fever, myocardial ischemia, acute drug withdrawal can all produce intraoperative tachycardia. After exclusion of all these causes still tachycardia persists quite often, it may be due to surgical stress. We have observed that small single shot dose of short acting $\beta$ blocker works efeffctively under such situations in patients without any risk factors. $\beta$ blockers are effective for suppressing atrial premature beats and controlling heart rate and conversion of focal atrial tachycardia, as well as preventing its recurrence, in many instances the result of increased sympathetic tone [4] such as after surgery [5]. $\beta$ blockers major adverse effects are hypotension, heart failure (contraindicated for patients class IV AHA) and bronchospasm and their use shall be withheld in such cases.

\section{References}

1. Hardman JG (1996) Sympathomimetic Drugs and Adrenergic Receptor Antagonists, em: Goodman \& Gillmans-The Pharmalogical Bosis of therapeutics. (9 $9^{\text {th }}$ edn), McGraw-Hill, New York, USA, pp. 199-182.

2. Priebe HJ (2005) Perioperative myocardial infarction--aetiology and prevention. Br J Anaesth 95(1): 3-19.

\begin{tabular}{|c|}
\hline Opinion \\
\hline Volume 2 Issue 4 - 2015 \\
\hline $\begin{array}{l}\text { Neha Hasija }{ }^{1} \text {, Preeti Gupta }{ }^{2} \text { and Rakesh } \\
\text { Garg }^{3 *}\end{array}$ \\
\hline $\begin{array}{l}{ }^{1} \text { Department of Anaesthesiology, India } \\
{ }^{2} \text { Assistant Professor of Cardiology, VMMC and Safdarjung } \\
\text { Hospital, India } \\
{ }^{3} \text { Assistant Professor, India }\end{array}$ \\
\hline $\begin{array}{l}\text { *Corresponding author: Rakesh Garg, Assistant Professor, } \\
\text { Dr BRAIRCH, All India Institute of Medical Sciences, Room } \\
\text { No 139, Ansari Nagar, New Delhi-110029, India, Tel: +91 } \\
\text { 98683978335; +91 9810394950; Email: } \\
\text { drrgarg@hotmail.com }\end{array}$ \\
\hline Received: March 22, 2015 | Published: April 18, 2015 \\
\hline
\end{tabular}

3. Fleisher LA, Beckman JA, Brown KA, Calkins H, Chaikof EL, et al. (2009) 2009 ACCF/AHA Focused Update on Perioperative Beta Blockade Incorporated Into the ACC/AHA 2007 Guidelines on Perioperative Cardiovascular Evaluation and Care for Noncardiac Surgery: A Report of the American College of Cardiology Foundation/ American Heart Association Task Force on Practice Guidelines. Circulation 120(21): e169-e276.

4. Singh BN (1973) Clinical aspects of the antiarrhythmic action of betareceptor blocking drugs.2. Pattern of response of common arrhythmias. N Z Med J 78(504): 482-486.

5. Blomstrom-Lundqvist C, Scheinman MM, Aliot EM (2003) ACCC/AHA/ ESC Guidelines for the management of patients with supraventricular arrhythmias A report of the American College of Cardiology/ American Heart Association task force on practice guidelines and the European Society of Cardiology committee for practice guidelines (committee to develop guidelines for the management of patients with supraventricular arrhythmias) developed in collaboration with the North American Society of Pacing and Electrophysiology. Eur Heart J 24: 1857-1897. 